Prepared in cooperation with Next Era Energy, Inc., U.S. Fish and Wildlife Service, East Bay Regional Park District, and The Peregrine Fund, Inc.

\title{
Distribution, Nesting Activities, and Age-Class of Territorial Pairs of Golden Eagles at the Altamont Pass Wind Resource Area, California, 2014-16
}

Open-File Report 2017-1035 



\section{Distribution, Nesting Activities, and Age-Class of Territorial Pairs of Golden Eagles at the Altamont Pass Wind Resource Area, California, 2014-16}

By Patrick S. Kolar and J. David Wiens

Prepared in cooperation with Next Era Energy, Inc., U.S. Fish and Wildlife Service, East Bay Regional Park District, and The Peregrine Fund, Inc.

Open-File Report 2017-1035

U.S. Department of the Interior

U.S. Geological Survey 


\section{U.S. Department of the Interior \\ RYAN K. ZINKE, Secretary}

\section{U.S. Geological Survey \\ William H. Werkheiser, Acting Director}

U.S. Geological Survey, Reston, Virginia: 2017

For more information on the USGS—-the Federal source for science about the Earth, its natural and living resources, natural hazards, and the environment-visit http://www.usgs.gov/ or call 1-888-ASK-USGS (1-888-275-8747).

For an overview of USGS information products, including maps, imagery, and publications, visit http://store.usgs.gov.

Any use of trade, firm, or product names is for descriptive purposes only and does not imply endorsement by the U.S. Government.

Although this information product, for the most part, is in the public domain, it also may contain copyrighted materials as noted in the text. Permission to reproduce copyrighted items must be secured from the copyright owner.

Suggested citation:

Kolar, P.S., and Wiens, J.D., 2017, Distribution, nesting activities, and age-class of territorial pairs of golden eagles at the Altamont Pass Wind Resource Area, California, 2014-16: U.S. Geological Survey Open-File Report 2017-1035, 18 p., https://doi.org/10.3133/ofr20171035.

ISSN 2331-1258 (online) 


\section{Contents}

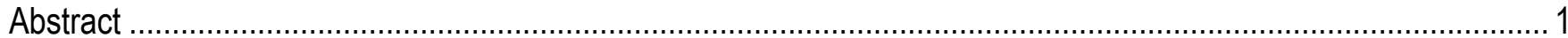

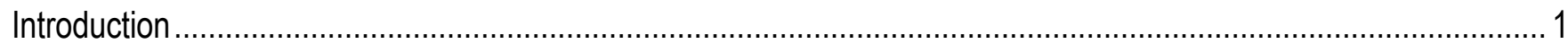

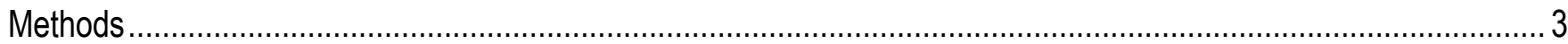

Study Area and Survey Design .................................................................................................

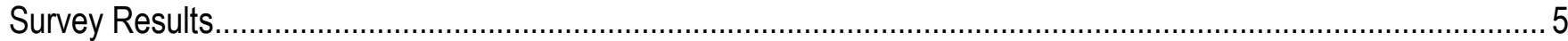

Occurrence of Subadult Pair Members ……………………....................................................................

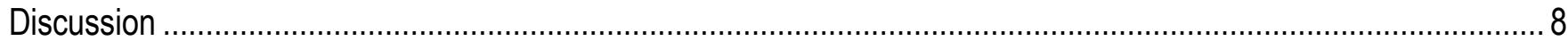

Territorial Pair Observations at Altamont Pass Wind Resource Area............................................................. 8

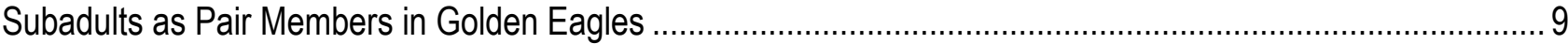

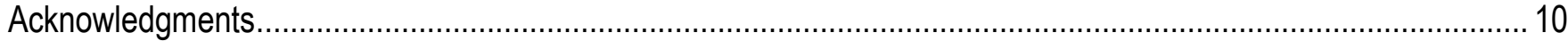

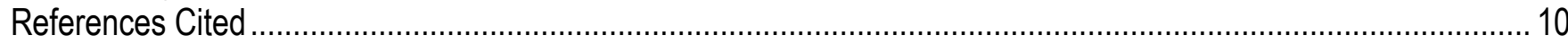

Appendix 1. Number of Completed Individual Surveys for Focal Sample Plots Overlapping with the Altamont Pass Wind Resource Area, California, 2014-16 .......................................................................... 13

Appendix 2. Observations of Territorial and Nesting Activities of Golden Eagles at the Altamont Pass Wind

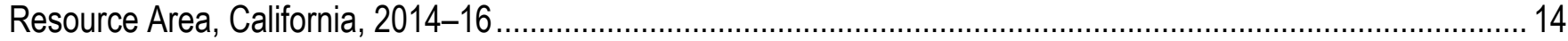

\section{Figures}

Figure 1. Map showing distribution of randomly selected sample plots (1,385 hectare hexagons) and a 3.2 kilometer $(\mathrm{km})$ buffer from wind turbines in the Altamont Pass Wind Resource Area (APWRA) that were repeatedly surveyed for golden eagles as part of a broader study (inset map) in the northern Diablo Range, California, 2014-16.

Figure 2. Map showing activity center locations (estimated as the mean annual location of observed territorial activities) for golden eagle (Aquila chrysaetos) pairs associated with the Altamont Pass Wind Resource Area, California, 2014-16.

\section{Table}

Table 1. Summary of nesting activity with number of young fledged in parentheses and incidence of subadult pair membership of territorial golden eagles in 13 randomly selected survey plots and within $3.2 \mathrm{~km}$ of wind turbines in the Altamont Pass Wind Resource Area, California, 2014-16.

\section{Conversion Factors}

International System of Units to U.S. customary units

\begin{tabular}{|c|c|c|}
\hline Multiply & By & To obtain \\
\hline \multicolumn{3}{|c|}{ Length } \\
\hline kilometer $(\mathrm{km})$ & 0.6214 & mile (mi) \\
\hline \multicolumn{3}{|c|}{ Area } \\
\hline hectare (ha) & 2.4710 & acre \\
\hline square kilometer $\left(\mathrm{km}^{2}\right)$ & 247.1 & acre \\
\hline square kilometer $\left(\mathrm{km}^{2}\right)$ & 0.3861 & square mile $\left(\mathrm{mi}^{2}\right)$ \\
\hline
\end{tabular}


This page left intentionally blank 


\title{
Distribution, Nesting Activities, and Age-Class of Territorial Pairs of Golden Eagles at the Altamont Pass Wind Resource Area, California, 2014-16
}

\author{
By Patrick S. Kolar and J. David Wiens
}

\begin{abstract}
The substantial numbers of golden eagles (Aquila chrysaetos) killed by collisions with oldgeneration wind turbines each year at the Altamont Pass Wind Resource Area (APWRA) in California has been well documented from previous studies. Few eagle nests have been documented in the APWRA, however, and adults and subadults $3+$ years of age killed by turbines were generally not associated with nearby territories. We searched a subset of randomly selected survey plots for territorial pairs of golden eagles and associated nesting attempts within the APWRA as part of a broader investigation of population dynamics in the surrounding northern Diablo Range. In contrast to limited historical observations from 1988 to 2013, our surveys documented up to 15 territorial pairs within 3.2 kilometers $(\mathrm{km})$ of wind turbines at the APWRA annually, 9 of which were not previously documented or only observed intermittently during historical surveys. We found evidence of nesting activity by adult pairs at least once during our study at six of these territories. We also determined that 23-36 percent of territories identified within $3.2 \mathrm{~km}$ of the APWRA had a subadult pair member, but that no pairs with a subadult member attempted to nest. These data will be useful to developers, wildlife managers, and future raptor studies in the area to evaluate and minimize the potential effects of wind energy or other development activities on previously unknown territorial pairs in the area.
\end{abstract}

\section{Introduction}

Located approximately 90-kilometers $(\mathrm{km})$ east of San Francisco, California, the Altamont Pass Wind Resource Area (APWRA) supports a broad diversity of resident, migratory, and wintering hawks and eagles (Orloff and Flannery, 1992). The local breeding population of golden eagles (Aquila chrysaetos) in the APWRA and broader Diablo Range is non-migratory, with pairs defending their territories year-round (Hunt and others, 2017; Wiens and others, 2015). Multiple studies of avian mortality at the APWRA have shown that substantial numbers of golden eagles, primarily aged as subadults and adults, are killed by collisions with wind turbines each year (Orloff and Flannery, 1992; Hunt, 2002; Smallwood and Thelander, 2008; ICF International, 2016). Expansive grassland supporting an abundance of California ground squirrels (Spermophilus beecheyii), a primary prey of golden eagles in the region (Hunt, 2002), and highly variable, rugged terrain that produces updrafts beneficial to foraging behaviors, suggest that lands in the APWRA may contain suitable breeding habitat for golden eagles (Wiens and others, 2015). Few eagle nests have been documented in the APWRA, however, and adults and subadults $3+$ years of age killed by turbines were generally thought to be floaters (that is, breeding-aged individuals that are prevented from reproducing by lack of a territory or nesting opportunities) (Steenhof and Newton, 2007; Penteriani and others, 2011). Orloff and Flannery (1992) 
surveyed all potential raptor nesting substrates in the APWRA in 1989 and found only one unused historical golden eagle nest. Jones and Stokes (1989) documented three nesting pairs of eagles 1.6-3.2 km outside of the APWRA boundary. Howell and DiDonato (1991) surveyed a small part of the APWRA for nesting raptors from 1988 to 1989 and found one eagle pair with nestlings. Smallwood and others (2009) recorded territorial behavior of golden eagles directed towards younger age-classes near wind turbines during behavioral observations from 1998-2016, but it was not known if these individuals were associated with nearby territories (S. Smallwood, independent consultant, written commun., 2016). Hunt (2002) noted that 18 regularly occupied territories of golden eagles occurred within $10 \mathrm{~km}$ of the APWRA, but with few observations of pairs using the area near turbines (Hunt, 2002; Hunt and Hunt, 2006). No nesting attempts were documented in the designated APWRA zoning boundary during limited, periodic surveys from 1994-2013, except one ground-nest observed in the mid-1990s that was constructed by golden eagles, but contained no indication that eggs were present (G. Hunt, The Peregrine Fund, oral commun., 2016).

We conducted repeated surveys for golden eagles near the APWRA during 2014-16 as part of a broader investigation of population dynamics in the northern Diablo Range of central California (fig. 1; also see Wiens and others, 2015). Objectives of this broader study were to (1) estimate the distribution and abundance of nesting and non-nesting territorial pairs of eagles in the Diablo Range, and (2) provide recommendations to improve strategies for monitoring population status of golden eagles in disturbed landscapes. Given the potential for high mortality of golden eagles near wind turbines (Hunt, 2002), and the disproportionate influence that decreased survival of territorial adults can have on stability of the local breeding population (Hunt and others, 2017), our surveys also included lands in the APWRA. As recommended by Driscoll (2010) and Pagel and others (2010), we also attempted to visually determine the age-class of eagle pair members, because the proportion of territorial subadults in a study population has been previously suggested as an indicator of poor-quality habitats or population decline (Balbontín and others, 2003; Ferrer and others, 2003; Hunt and others, 2017).

Current management guidelines for golden eagles (U.S. Fish and Wildlife Service, 2013) consider occupied territories overlapping with wind-energy project boundaries to potentially be at risk of disturbance, so surveys are recommended within an area equivalent to the average nearest-neighbor distance of simultaneously occupied territories (approximately $3.2 \mathrm{~km}$ in our study area) prior to construction of turbines and related infrastructure. To determine the distribution and potential number of territorial pairs specific to this area of management interest at the APWRA, we delineated the survey effort from our broader study beyond the designated APWRA zoning boundary using a $3.2 \mathrm{~km}$ buffer around old and existing wind-turbines (fig. 1; see Hunt, 2002; Hunt and Hunt, 2006). This report summarizes our observations of territorial pairs of golden eagles and nesting activities in close proximity $(3.2 \mathrm{~km})$ of current and historically operational wind turbines in the APWRA. These data will be useful to developers, wildlife managers, and future raptor studies in the area to evaluate and minimize the potential effects of renewable energy or other development activities on territorial eagle pairs near the APWRA and the local population. 


\section{Methods}

\section{Study Area and Survey Design}

The 5,170- $\mathrm{km}^{2}$ study area encompassed all areas in public or private ownership in the northern Diablo Range, California, and included the APWRA, which was located in the northeastern quadrant of the study area (fig. 1; see Wiens and others, 2015, for details). Suitable nesting substrates for golden eagles near the APWRA primarily included towers along a 230 kilovolt $(\mathrm{kV})$ transmission line, limited cliff faces on small rock outcrops, and sparsely distributed eucalyptus (Eucalyptus spp.) and oak (Quercus spp.) trees. In 2005, wind energy developers began to repower parts of the APWRA by gradually decommissioning old-generation wind turbines, generally those less than 660 kilowatts, and replacing them with fewer larger turbines with greater generating capacity (Smallwood and Karas, 2009; ICF International, 2016). The remaining old-generation wind turbines were subjected to seasonal shutdowns, individually removed to reduce fatalities, or became non-operational due to mechanical breakdown (ICF International, 2016), but most were operational until late 2015 and many were removed from the landscape by fall 2016 (fig. 1).

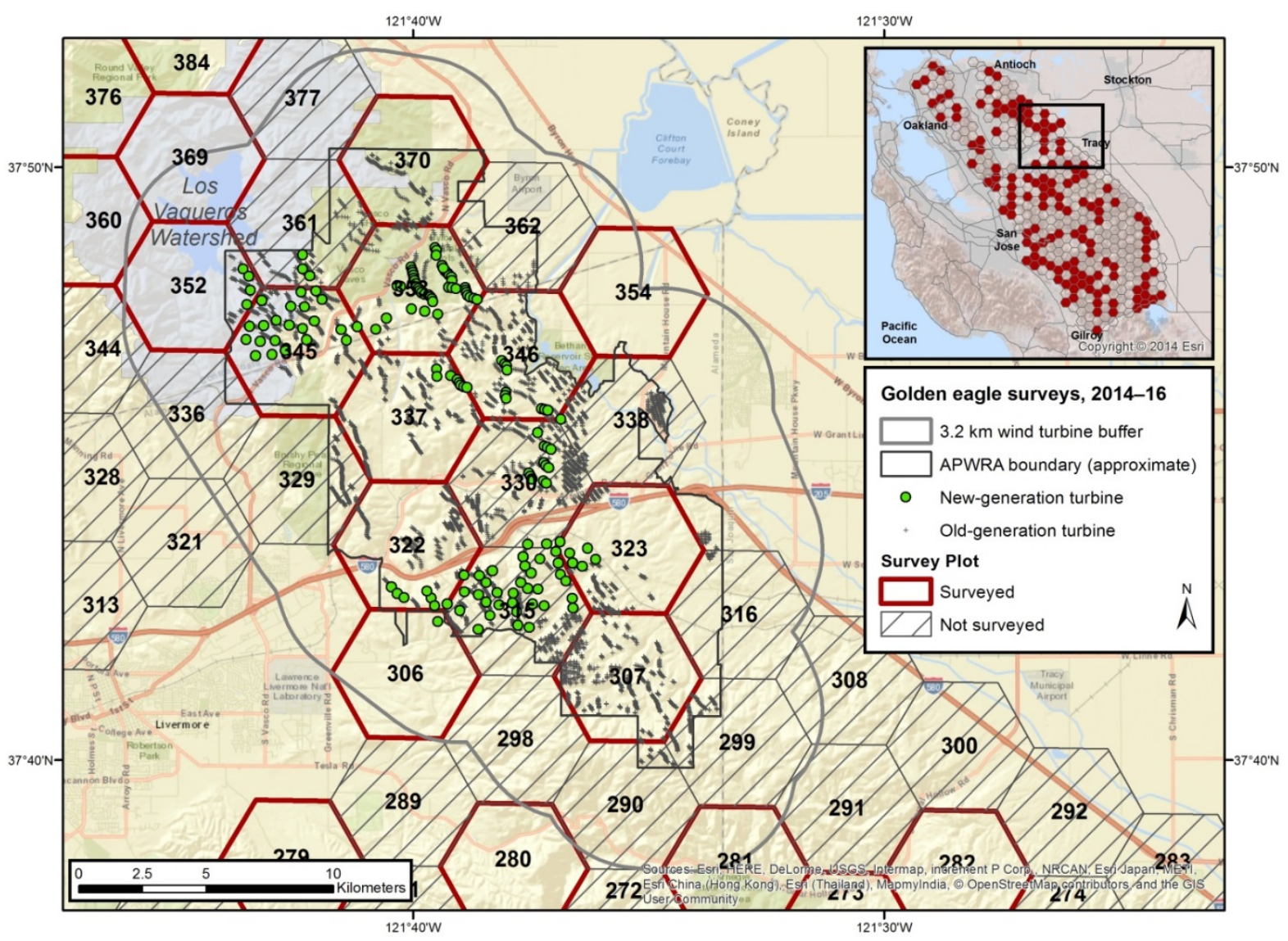

Figure 1. Map showing distribution of randomly selected sample plots (1,385 hectare hexagons) and a 3.2 kilometer $(\mathrm{km})$ buffer from wind turbines in the Altamont Pass Wind Resource Area (APWRA) that were repeatedly surveyed for golden eagles as part of a broader study (inset map) in the northern Diablo Range, California, 201416. Wind turbines are represented as historical old-generation (40-750 kilowatt, currently non-operational and mostly removed) and new-generation (660 kilowatt-2.3 megawatt) that became operational between 2005 and 2016. 
We used a broad-scale survey design to estimate occupancy, reproduction, and abundance of breeding and non-breeding golden eagles in the Diablo Range study area, including the APWRA (Wiens and others, 2015). Areas targeted for repeated surveys for eagles were selected randomly from a grid of equal-sized (1,385 hectares [ha]) hexagonal cells overlaid on the study area (figs. 1 and 2). The size of each hexagon cell (survey plot) corresponded to the estimated mean size of an eagle territory (about 1,385 ha; Wiens and others, 2015; Hunt and others, 2017).

We conducted repeated surveys of selected sample plots overlapping with the APWRA $(n=13$; fig. 1) up to four times during the breeding season (December-July), following a standardized protocol for determining occupancy and reproductive status of eagles (Wiens and others, 2015). Additional surveys were done, when necessary, to determine the outcome of nesting attempts. We partitioned survey periods by using four developmental stages of the breeding season: courtship (December 15February 28), incubation (March 1-April 30), nestling (May 1-June 15), and the fledging period (June 16-July 30) (G. Hunt and T. Hunt, The Peregrine Fund, oral commun., 2016). On each survey, we established 1-4 observation points (OPs) on selected ridges and hilltops to provide complete coverage of the focal sample plot. A single observer then searched for evidence of occupancy and reproduction by golden eagle pairs for up to a 4-hour observation period (Pagel and others, 2010 U.S. Fish and Wildlife Service, 2013) using binoculars and high-powered spotting scopes $(12-40 \times 60 \mathrm{~mm})$ to observe territorial behaviors and nesting activities. When pairs were observed in focal plot boundaries, we obtained more precise information on their areas of activity by watching from closer OPs, when possible, without causing disturbance. On each visit we characterized a sample plot as being in one of three possible observation states: (1) no eagles detected; (2) pair detected but no evidence of nesting observed; or (3) pair detected with evidence of successful reproduction ( $\geq 1$ young fledged). Thus, sites could only be attributed to state ' 3 ' during the last two sampling periods of the breeding season. Any follow-up surveys that were required to complete the survey (that is, complete the 4-hour observation period, confirm suspected observation state, or survey remaining parts of the survey plot) were generally done in less than 7 days. We considered a sample plot to be occupied by a territorial pair if we observed (1) a golden eagle pair copulating, undulating, or perching together; (2) an incubating eagle in a nest or a female with a brood patch; or (3) nestlings or fledglings in or near a nest (Steenhof and Newton, 2007). Pairs were determined to be nesting if we observed adults or subadults in incubation posture, nests with eggs/eggshells, or nestlings or fledglings present. Nesting attempts were considered to be successful if nestlings or fledglings were greater than 80 percent of average fledging age (approximately 51 days old; Kochert and others, 2002; Steenhof and Newton, 2007).

We ensured territorial pairs were not double-counted by using a combination of methods. In most cases we attempted to observe adjacent pairs simultaneously to confirm they were distinct and occupied different sites, and not simply the same pair using multiple survey plots. Most often, this required that we use OPs between two suspected activity center locations where we could simultaneously observe pairs undulating in response to one another, or perching in frequently used areas near nests. 
We attempted to classify all golden eagles detected as juveniles, subadults, or adults based on visible plumage characteristics (see Bloom and Clark, 2001; Good and others, 2004). Generally, we determined age-class based on a combination of presence/absence of a tawny bar on the upper side of the wing, conspicuous white patches on the underside of the wing, proportion of white at the base of tail feathers, and molt patterns. We classified eagles as juveniles if they lacked a tawny bar on the upper wing, showed conspicuous white patches on the underside of the wing, and had a large proportion of white at the base of tail feathers. We classified eagles as subadults if the tawny bar was present with little or no white patches in the wings, and white at the base of at least some tail feathers. We classified eagles as adults if they had a tawny bar with little to no white in the wings and at the base of tail feathers. Given the difficulty in classifying golden eagles in flight by age class, especially retained subadult tail feathers as they transition to adulthood (Liguori, 2004), we attempted to observe plumage characteristics from multiple angles (that is, tail spread and folded) and during different behaviors (such as, eagles perching, flying, copulating, or preening). We attempted to determine the sex of subadult pair members, when possible, through observations of copulations and the relative size difference between pair members when perching next to one another.

We mapped perches, flight paths, territorial displays, and nest locations observed during surveys on topographic maps. Using this information, we estimated the approximate center of activity for each eagle pair we detected using ArcGIS ${ }^{\mathrm{TM}}$ software (v. 10.1). Activity center locations were considered to be the approximate location of territorial displays or other areas most often used by territorial birds during our observations (for example, a nest with young, focal area of copulations, or frequently-used perches). The activity center is not meant to be a representation of the territory boundaries, but was simply used to determine the general location of focal behavioral observations relative to the boundary of the survey plot.

\section{Survey Results}

We surveyed 133-136 selected plots across the broader Diablo Range study area each year from 2014 to 2016, 13 of which overlapped with the APWRA (fig. 2). We completed 2-7 surveys at plots overlapping with the APWRA each year (appendix 1). Seven different observers completed 159 surveys at these focal survey plots, but most (62.2 percent) were done by one individual; three other observers each did 9.0-10.5 percent of surveys, and the rest (0.7-6.2 percent) were completed by the remaining three observers.

We identified 15 territorial pairs of golden eagles with activity centers estimated to be within 3.2 $\mathrm{km}$ of historically operational wind turbine locations at the APWRA (fig. 2; appendix 2). Many of the pairs were detected on numerous occasions, both during different survey occasions in selected focal plots and during surveys of adjacent plots. An additional adult pair nested each year in one of these selected survey plots (369), but their center of activity and associated nests were outside the $3.2-\mathrm{km}$ APWRA buffer. All 15 territories identified in the APWRA buffer were occupied by a pair of golden eagles from 2014 to 2016 except two-Silva, which was outside our focal survey area and not detected in 2014, and Vaquero Farms, where we only detected a lone territorial adult in 2014. The center of activity for two territories, Midway Road and Windy Valley, shifted from our selected plots in 2015 to just outside these areas in 2016 (appendix 2). 


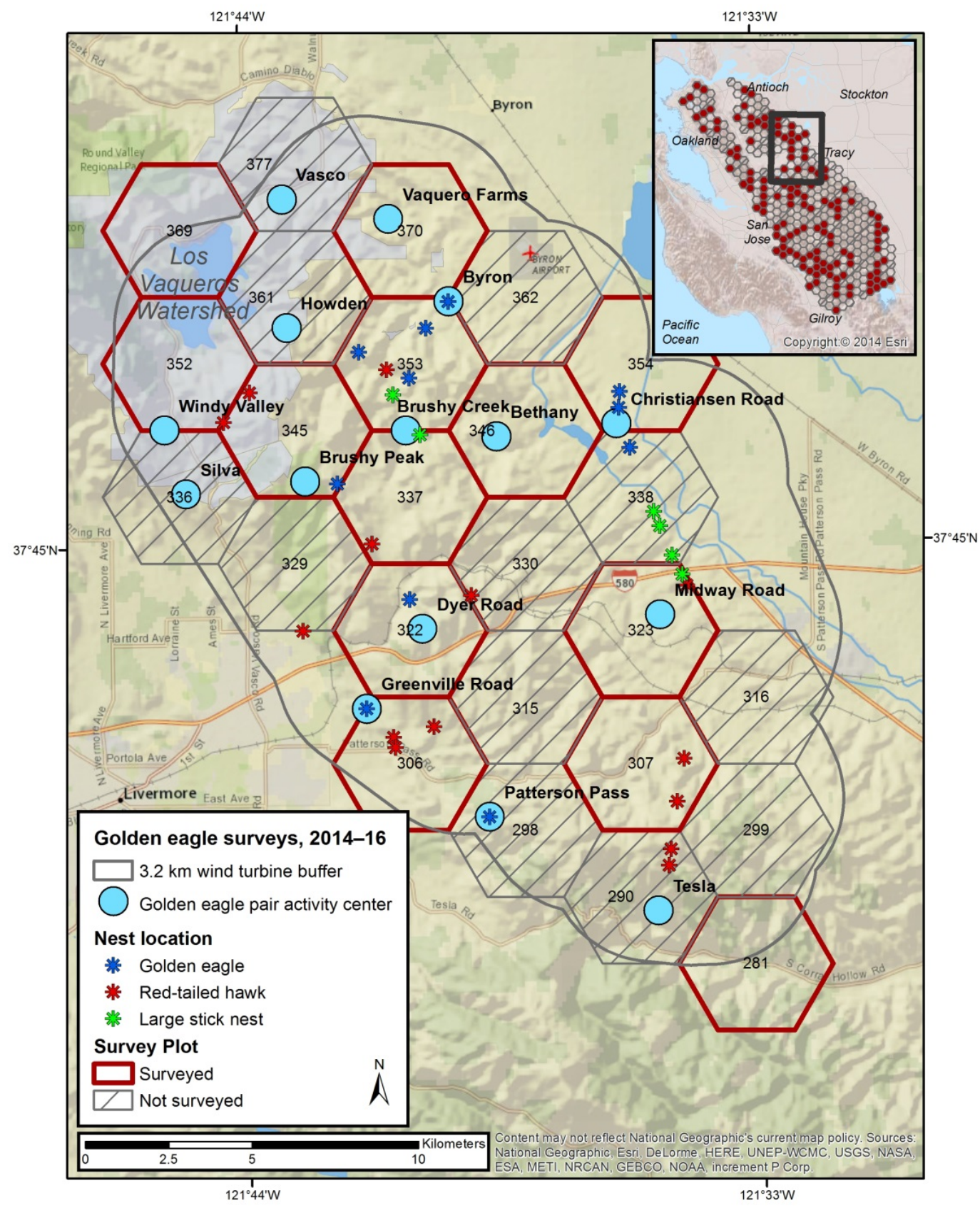

Figure 2. Map showing activity center locations (estimated as the mean annual location of observed territorial activities) for golden eagle (Aquila chrysaetos) pairs associated with the Altamont Pass Wind Resource Area, California, 2014-16. Also displayed are nests with evidence of construction, refurbishment, or nesting activity (that is, incubating adults, eggs, nestlings, or fledglings) by golden eagles and red-tailed hawks (Buteo jamaicensis). Survey plots outside of the 3.2-kilometer $(\mathrm{km})$ buffer from wind turbines and golden eagle nest locations on the Los Vaqueros Watershed are not displayed. 
We found evidence of nesting activity at least once at 6 of the 15 identified territories from 2014 to 2016 (table 1), none of which was by pairs with a subadult. Areas outside our selected plots were not monitored extensively aside from those in the part of the 3.2-km buffer overlapping with the Los Vaqueros Watershed (fig. 2), which was part of a separate long-term study (The Wildlife Project, 2016; H. T. Harvey and Associates, 2017). Of the territorial pairs in selected plots, three nested in 2014, of which one failed, and three young fledged between the other two nests. In 2015, three pairs nested, but all failed for unknown reasons during incubation or the early nestling stage. In 2016, three pairs nested, of which two failed during the early incubation or nestling stage, and the other fledged a single young. Of the pairs identified on the Los Vaqueros Watershed, but with activity centers outside our selected plots in the 3.2-km buffer, one pair fledged a single young in 2014 and two pairs each fledged one young in 2016 (The Wildlife Project, 2016; H. T. Harvey and Associates, 2017). We also found one failed nesting attempt at the Patterson Pass territory outside of our selected plots in 2016. During our surveys, we documented large stick nests being used by red-tailed hawks (Buteo jamaicensis) and common ravens (Corvus corax), in addition to several unused large stick nests, all of which could potentially be suitable for use by golden eagles, given their size and proximity to the activity centers of territorial pairs in the area (fig. 2).

\section{Occurrence of Subadult Pair Members}

We observed a subadult pair member at least once at 5 of the 15 territories identified near the APWRA (table 1; appendix 1). In four of these cases, we observed changes in the age of territory holders from both adult pair members to one subadult pair member the following year. Two additional territories were occupied by an adult and a pair member that could not conclusively be determined to be an adult or subadult from one survey to the next. Hunt and Hunt (2006) observed that some adults showed pale areas in the tail feathers, making them sometimes difficult to distinguish from third-year subadults (also see Bloom and Clark, 2001). In most cases, however, it is likely these eagles were indeed subadults, but with white bases of outer tail feathers that were concealed by inner adult tail feathers, making them appear to be adults when their tails were folded (Bloom and Clark, 2001; Liguori, 2004). It is also possible there was some within-season turnover of territorial pair members and these were different individuals. Nearly all other subadult eagles were consistently aged as such during different surveys and, in most cases, by different observers. 
Table 1. Summary of nesting activity (with number of young fledged in parentheses) and incidence of subadult pair membership of territorial golden eagles (Aquila chrysaetos) in 13 randomly selected survey plots and within 3.2 kilometers $(\mathrm{km})$ of wind turbines in the Altamont Pass Wind Resource Area, California, 2014-16.

\begin{tabular}{l|lll}
\hline \multirow{2}{*}{\multicolumn{1}{c}{ Nesting activity }} & \multicolumn{3}{c}{ Survey Year } \\
\cline { 2 - 4 } & $\mathbf{2 0 1 4}$ & $\mathbf{2 0 1 5}$ & $\mathbf{2 0 1 6}$ \\
\hline Number of territorial pairs in sample plots $^{1}$ & 8 & 10 & 8 \\
Number of territorial pairs in 3.2-km radius $^{2}$ & 13 & 15 & 15 \\
Nesting attempts $^{2}$ in sample plots & $3(3)$ & $3(0)$ & $3(1)$ \\
Total nesting attempts $^{\text {Maximum number of territorial subadults }}{ }^{3}$ & $4(4)$ & $3(0)$ & $6(3)$ \\
Number of territorial eagles aged $_{\text {Maximum percentage of territorial pairs with one subadult }^{4}}$ & 3 & 4 & 5 \\
\hline
\end{tabular}

${ }^{1}$ Excludes one golden eagle pair detected in a selected survey plot, but outside the 3.2-km APWRA buffer.

${ }^{2}$ Adults in incubation posture, nests with eggs/eggshells, nestlings or fledglings present.

${ }^{3}$ Includes two territories with individuals that could not consistently be identified as adults or subadults.

${ }^{4}$ Percentage of territories with one subadult pair member.

\section{Discussion}

\section{Territorial Pair Observations at Altamont Pass Wind Resource Area}

In contrast to limited historical observations from 1988 to 2013, our annual surveys documented at least 15 territorial pairs with activity centers located within $3.2 \mathrm{~km}$ of wind turbines at the APWRA, 9 of which were not previously detected during the 1994-2000 surveys or only observed intermittently (Hunt and Hunt, 2006). More recent survey efforts near the APWRA, such as surveys of raptor nests along transmission lines in 2012-13 (Garcia and Associates, 2013) and concurrent golden eagle surveys in a 10-mi radius of adjacent Site 300 (Lawrence Livermore Laboratory) in 2014 (Fratanduono, 2014), also documented some of these same territorial pairs. We found evidence of nesting in four of these territories overlapping our selected survey plots with apparent productivity in these areas ranging from 0.0 to 0.38 young/pair; three of the pairs in focal survey areas nested each year, but only fledged four young during our study. Of the other five to seven territories located outside these plots and within 3.2 $\mathrm{km}$ of wind turbines annually, two of three nested and fledged two young.

It is not clear if the territorial pairs we observed at the APWRA during our study were missed during earlier surveys, or were recently established, possibly because breeding habitat is now more suitable to occupancy by pairs for reasons related to current repowering efforts or increased prey density. Hunt (2002) suggested that territorial pairs closer to the APWRA would experience higher rates of mortality than those from farther away because of the increased risk of collisions with wind collisions. In that scenario, territories near the APWRA would be more likely to be occupied intermittently from one year to the next, depending upon the availability of floaters as replacements for dead breeders. In contrast, we detected territorial eagle pairs in nearly the same survey plots every year of our study, with some eagles also observed by others during 2012 and 2013, suggesting these territories were likely to be re-occupied from one breeding season to the next. Recent analyses have suggested that removing older turbines has decreased the number of golden eagle collisions in some parts of the APWRA (Smallwood and Karas, 2009; ICF International, 2016), potentially allowing 
golden eagles to establish territories or maintain stable occupancy of these areas for longer periods compared with the years prior to repowering. However, it is not clear if these projects are representative of the entire area so similar reductions in fatalities might not be consistent across the APWRA. Many of the old-generation wind turbines were still operational throughout the APWRA during 2012-15 when most of these territories appear to first have been documented as being occupied. In the northern part of the APWRA, two wind energy projects were repowered prior to the beginning of our study, Buena Vista in 2007 and Vasco Winds in 2011. Four of six of the territories in this area were already known prior to repowering, but only those on the Los Vaqueros Reservoir were monitored consistently for occupancy and reproduction. Diablo Winds, located in the middle of the APWRA, was repowered in 2005 near two territories not previously documented. However, these turbines were interspersed among numerous oldgeneration turbines that were still operational until at least late 2015. Pre-construction raptor nesting surveys do not appear to have been done for these repowered projects, so it is unclear if all the territories we documented were occupied beforehand. The remaining additional territories recorded during recent years were either outside of these repowered areas or in the southern part of the APWRA. All these territories were determined to be occupied prior to the repowering of the nearby Golden Hills project area in late 2015 when old-generation turbines were still operational.

\section{Subadults as Pair Members in Golden Eagles}

We determined that 23-36 percent of territories identified within $3.2 \mathrm{~km}$ of the APWRA had a subadult pair member. None of the pairs consisted of two subadults, and we found no evidence of nesting attempts by mixed-age pairs. Thus, of the 26-30 individual pair members observed annually, 12-18 percent of all territory-holders that could be aged were subadults, much greater than earlier estimates from a larger sample of territories monitored within $30 \mathrm{~km}$ of the APWRA during 1996-2013 (0.0-3.6 percent; Hunt and others, 2017). Whether the high incidence of subadult pair members we observed at territories near the APWRA reflects a greater-than-average mortality at these sites is currently unknown, but warrants further investigation. Most breeding raptors include a small proportion of territorial subadults depending upon favorable conditions (that is, spatial variation in prey availability) and territory vacancy (Newton, 1979). A high incidence of subadult pair membership could be an indication that the floating segment of the population is not sufficient to sustain breeder deaths, that breeding pairs consider these territories lower quality than elsewhere in the area, or that the population is expanding (Sánchez-Zapata and others, 2000; Hunt, 2002; Balbontín and others, 2003; Margalida and others, 2008). The percentage of territories with one subadult pair member we documented near the APWRA is higher than most others reported in the literature (Steenhof and others, 1983; Sánchez-Zapata and others, 2000), but is similar to proportions reported in parts of Scotland and the French and Italian Alps during high levels of human persecution (Pedrini and Sergio, 2001; Whitfield and others, 2004). Monitoring the proportion of territories with subadults has been criticized as a poor choice to assess population stability, but may be useful in areas where adult mortality is a primary cause of population decline (Katzner and others, 2007) or in areas that appear to be a population sink (Whitfield and others, 2004), such as the APWRA has been considered (Hunt, 2002; Katzner and others, 2016; Hunt and others, 2017), and in combination with other demographic parameters. 
Subsequent analyses from our surveys in the APWRA and surrounding Diablo Range study area will provide quantitative information on spatial patterns of occupancy, reproduction, and abundance of a population of golden eagles exposed to a large wind-energy facility during a period of extreme drought. These data will be valuable for predicting future trends in the population demography of golden eagles in relation to current repowering efforts in the APWRA under various climatic scenarios, permitting land managers and stakeholders to target mitigation efforts on areas or habitats that make disproportionate contributions to population productivity and persistence. Understanding factors influencing the spatial distribution and reproductive contributions of territorial pairs in the APWRA and surrounding lands are important for predicting the potential interactive effects of drought and increased temperatures related to climate change with the current replacement of old-generation wind turbines with fewer, larger ones in this region.

\section{Acknowledgments}

We are indebted to Step Wilson, Caleb Murphy, Colleen Lenihan, Eric Jepsen, Mandy Murphy, and Harv Wilson for their assistance with surveys of golden eagles in the APWRA. We thank Doug Bell, Joe DiDonato, Danika Tsao, and Shawn Smallwood for providing historical information on locations of golden eagles in the area and additional logistical support. We are especially grateful to Renee Culver with Next Era Energy for coordinating access to wind energy facilities and privatelyowned land, and assisting with other critical aspects of this research in the APWRA. Finally, Grainger and Terry Hunt provided considerable contributions to the design and implementation of this study, and we also thank them for their valuable feedback on this manuscript. Our work in the APWRA would not have been possible without support from the East Bay Regional Park District, California State Parks, California Department of Water Resources, Contra Costa Water District, and the many private landowners that provided us with permission to access their lands to survey golden eagles. We thank two anonymous reviewers for valuable feedback on revisions to this manuscript.

\section{References Cited}

Balbontín, J., Penteriani, V., and Ferrer, M., 2003, Variations in the age of mates as an early warning signal of changes in population trends?-The case of Bonelli's eagle in Andalusia: Biological Conservation, v. 109, p. 417-423.

Bloom, P.H., and Clark, W.S., 2001, Molt and sequence of plumages of golden eagles and a technique for in-hand ageing: North American Bird Bander, v. 26, p. 97-116.

Driscoll, D., 2010, Protocol for golden eagle occupancy, reproduction, and prey population assessment: Apache Junction, Arizona, American Eagle Research Institute, 55 p.

Ferrer, M., Penteriani, V., Balbontín, J., and Pandolfi, M., 2003, The proportion of immature breeders as a reliable early warning signal of population decline-Evidence from the Spanish Imperial Eagle in Doñana: Biological Conservation, v. 114, p. 463-466.

Fratanduono, M.L., 2014, Final report bald and golden Eagle territory surveys for the Lawrence Livermore National Laboratory: Livermore, California, Lawrence Livermore National Laboratory, No. LLNL-SR-664876, 2014.

Garcia and Associates, 2013, 2012-2013 raptor surveys for the Pittsburg-Tesla $230 \mathrm{kV}$ Reconductoring Project: San Ramon, California, Report to Pacific Gas and Electric Company.

Good, R.E., Nielson, R.M., Sawyer, H.H., and McDonald, L.L., 2004, Population level survey of Golden Eagles (Aquila chrysaetos) in the Western United States: U.S. Fish and Wildlife Publications, Paper 472, http://digitalcommons.unl.edu/usfwspubs/472. 
Howell, J.A., and DiDonato, J.E., 1991, Assessment of avian use and mortality related to wind turbine operations: Livermore, California, Report to U.S. Windpower, Inc.

H. T. Harvey and Associates, 2017, Los Vaqueros Reservoir project annual golden eagle monitoring report 2016: Prepared for Contra Costa Water District, Concord, California.

Hunt, W.G., 2002, Golden eagles in a perilous landscape-Predicting the effects of mitigation for wind turbine blade-strike mortality: Sacramento, California, Consultant Report to California Energy Commission under contract P500-02-043F, Public Interest Energy Research, 72 p.

Hunt, W.G., and Hunt, T.L., 2006, The trend of golden eagle territory occupancy in the vicinity of the Altamont Pass Wind Resource Area-2005 survey: California Energy Commission, PIER EnergyRelated Environmental Research, CEC-500-2006-256, 11 p.

Hunt, W.G., and Hunt, T.L., 2013, Golden eagle territory occupancy and reproduction in the vicinity of the Altamont Pass Wind Resource Area-2013 survey results: Oakland, California, East Bay Regional Parks District.

Hunt, W.G., Wiens, J.D., Law, P.R., Fuller, M.R., Hunt, T.L., Driscoll, D.E., and Jackman, R.E., 2017, Quantifying the demographic cost of human-related mortality to a raptor population: Plos One 12(2): e0172232. doi:10.1371/journal.pone.0172232.

ICF International, 2016, Altamont Pass Wind Resource Area bird fatality study, monitoring years 20052013: Sacramento, California, ICF International, Prepared for Alameda County Community Development Agency, accessed November 7, 2016 at https://www.acgov.org/cda/planning/landuseprojects/documents/Final_APWRA_BirdFatalityStudy20 05-2013_041816.pdf.

Jones \& Stokes, 1989, Results of biological resource inventories and habitat evaluations in the Kellogg Creek Watershed: Concord, California, Prepared for James M. Montgomery, Consulting Engineers, Inc., and Contra Costa Water District.

Katzner, T., Milner-Gulland, E.J., and Bragin, E., 2007, Using modeling to improve monitoring of structured populations-Are we collecting the right data?: Conservation Biology, v. 21, no. 1, p. 241252.

Katzner, T.E., Nelson, D.M., Braham, M.A., Doyle, J.M., Fernandez, N.B., Duerr, A.E., Bloom, P.H., Fitzpatrick, M.C., Miller, T.A., Culver, R.C., and Braswell, L., 2016, Golden eagle fatalities and the continental-scale consequences of local wind-energy generation: Conservation Biology, v. 31, no. 1, doi:10.1111/cobi.12836.

Kochert, M.N., Steenhof, K., McIntyre, C.L., and Craig, E.H., 2002, Golden eagle (Aquila chrysaetos), in Poole, A., and Gill, F. (eds.), The Birds of North America, no. 684, Philadelphia, The Birds of North America Inc., p. 1-44.

Liguori, J., 2004, How to age golden eagles - Techniques for birds observed in flight: Birding, v. June 2004, p. 278-283.

Margalida, A., Mañosa, S., Gonzalez, L.M., Ortega, E., Sánchez, R., and Oria, J., 2008, Breeding of non-adults and effects of age on productivity in the Spanish Imperial Eagle Aquila adalberti: Ardea, v. 96 , no. 2, p. 173-180.

Newton, I., 1979, Population ecology of raptors: London, U.K., T. \& A.D. Poyser, 399 p.

Orloff, S. and Flannery, A, 1992, Wind turbine effects on avian activity, habitat use and mortality in Altamont Pass and Solano County Wind Resource Areas, 1989-91. California Energy Commission.

Pagel, J.E., Whittington, D.M., and Allen, G.T., 2010, Interim golden eagle inventory and monitoring protocols and other recommendations: U.S. Fish and Wildlife Service, Division of Migratory Bird Management. 
Pedrini, P., and Sergio, F., 2001, Density, productivity, diet, and human persecution of golden eagles (Aquila chrysaetos) in the central-eastern Italian Alps: Journal of Raptor Research, v. 35, no. 1, p. 4048.

Penteriani, V., Ferrer, M., and Delgado, M.D.M., 2011, Floater strategies and dynamics in birds, and their importance in conservation biology-Towards an understanding of nonbreeders in avian populations: Animal Conservation, v. 14, no. 3, p. 233-241.

Sánchez-Zapata, J.A., Calvo, J.F., Carrete, M., and Martínez, J.E., 2000, Age and breeding success of a Golden Eagle Aquila chrysaetos population in southeastern Spain: Bird Study, v. 47, no. 2, p. 235237.

Smallwood, K.S., and Thelander, C., 2008, Bird mortality in the Altamont Pass wind resource area, California: The Journal of Wildlife Management, v. 72, no. 1, p. 215-223.

Smallwood, K.S., and Karas, B., 2009, Avian and bat fatality rates at old-generation and repowered wind turbines in California: The Journal of Wildlife Management, v. 73, no. 7, p. 1,062-1,071.

Steenhof, K., Kochert, M.N., and Doremus, J.H., 1983, Nesting of subadult golden eagles in southwestern Idaho: Auk, v. 100, p. 743-747.

Steenhof, K., and Newton, I., 2007, Assessing nesting success and productivity, in Bird, D.E., and Bildstein, K.L., (eds.), Raptor research and management techniques: Blaine, Washington, Hancock House Publishers, p. 181-192.

The Wildlife Project, 2016, Los Vaqueros watershed annual golden eagle monitoring report 2015: Prepared for Contra Costa Water District, Concord, California.

U.S. Fish and Wildlife Service, 2013, Eagle conservation plan guidance, module 1-Land-based wind energy, version 2: Department of the Interior, U.S. Fish and Wildlife Service, Division of Migratory Bird Management.

Watson, J., 2010, The golden eagle (second ed.): London, U.K., T. \& A.D. Poyser, 448 p.

Whitfield, D.P., Fielding, A.H., McLeod, D.R.A., and Haworth, P.F., 2004, The effects of persecution on age of breeding and territory occupation in golden eagles in Scotland: Biological Conservation, $\mathrm{v}$. 118 , no. 2, p. 249-259.

Wiens, J.D., Kolar, P.S., Fuller, M.R., Hunt, W.G., and Hunt, T., 2015, Estimation of occupancy, breeding success, and predicted abundance of Golden Eagles (Aquila chrysaetos) in the Diablo Range, California, 2014: U.S. Geological Survey Open-File Report 2015-1039, 23 p., http://dx.doi.org/10.3133/ofr20151039. 


\section{Appendix 1. Number of Completed Individual Surveys for Focal Sample Plots Overlapping with the Altamont Pass Wind Resource Area, California, 2014-16}

[Number of different observers are shown in parentheses]

\begin{tabular}{c|ccc}
\hline Focal sample plot No. & $\mathbf{2 0 1 4}$ & $\mathbf{2 0 1 5}$ & $\mathbf{2 0 1 6}$ \\
\hline 281 & $4(1)$ & $3(1)$ & $2(1)$ \\
306 & $3(1)$ & $3(1)$ & $3(1)$ \\
307 & $3(2)$ & $3(1)$ & $2(1)$ \\
322 & $3(2)$ & $3(1)$ & $4(1)$ \\
323 & $3(2)$ & $3(1)$ & $4(1)$ \\
337 & $3(2)$ & $3(1)$ & $3(1)$ \\
345 & $3(2)$ & $4(1)$ & $3(1)$ \\
346 & $3(2)$ & $4(1)$ & $4(1)$ \\
352 & $6(1)$ & $3(1)$ & $2(1)$ \\
353 & $5(3)$ & $5(2)$ & $4(2)$ \\
354 & $3(1)$ & $4(2)$ & $4(1)$ \\
369 & $7(1)$ & $4(1)$ & $6(1)$ \\
370 & $3(2)$ & $4(2)$ & $3(1)$ \\
\hline
\end{tabular}




\section{Appendix 2. Observations of Territorial and Nesting Activities of Golden Eagles at the Altamont Pass Wind Resource Area, California, 2014-16}

\section{Telsa}

The Telsa territory was located outside our selected survey plots, but a pair of eagles has been detected throughout survey plot 290, northwestern survey plot 281, and in the APWRA boundary in southern survey plot 307 from 2014 to 2016. This pair was not monitored to determine nesting attempts, and no historical nests have been located. In 2014, one of the pair members was a subadult; in 2015 , both pair members were adults; and in 2016, we did not obtain sufficient observations to determine the age of pair members.

\section{Patterson Pass}

The activity center for the pair associated with this territory was primarily outside our focal survey area, but they were determined to be adults and observed perching together, hunting, and undulating throughout survey plot 298, in western survey plot 307, in eastern survey plot 306, and in southern survey plot 315 each year of our study. A pair was observed flying with nesting material in survey plot 298 in 2014, but we were unable to confirm nesting in this area until 2016 when we obtained landowner permission to access the area. At that time, we found a dead 2-4 week old nestling in the only known nest; the cause of death was unknown.

\section{Greenville Road}

An adult pair has been detected during nearly every survey occasion in northern survey plot 306 and southern survey plot 322, and to the west towards Greenville Road outside these plots. We found evidence of nesting approximately $1.3 \mathrm{~km}$ from the nearest wind turbine during 2 of the 3 years of our study. Two young fledged from the only known nest in 2014 and the pair attempted to nest, but failed in 2016. In mid-May 2016, we found a dead adult golden eagle below a new-generation wind turbine 1.4 $\mathrm{km}$ from the nest, along a ridge frequently used by the Greenville Road and Dyer Road pairs. We observed two adults perching and hunting together near the Greenville Road nest when we found the dead adult nearby, suggesting that the dead adult was not from this territory or that it was but had been replaced during the nearly 2.5 months since the pair was last observed together, during incubation. This site was unknown to other researchers in the area, but had also been monitored by the California Department of Water Resources staff since 2014 (D. Tsao, California Department of Water Resources, oral commun., 2016). 


\section{Dyer Road}

During our surveys in 2014 and 2015, the Dyer Road pair consisted of two adults, and they were primarily observed undulating, perching, and hunting in northwestern survey plot 322, southeastern survey plot 329, and southern survey plot 337. However, during surveys in 2016, one pair member, possibly the male, appeared to be a second- or third-year subadult, as evident by the large amount of white at the base of the tail feathers and they were observed focusing their activity throughout survey plot 322 and northwestern survey plot 315 . We found no evidence of nesting by the pair associated with this territory, but in 2014 they were observed adding material to an existing nest in a eucalyptus tree that was later used by common ravens. In 2015, a pair was seen perching on the hillside above the nest and frequently flying over and defending the area. We observed no other activity near the nest in 2015 aside from red-tailed hawks possibly adding nesting material. During our surveys in 2016, we found the nest to be occupied by ravens again, but in May discovered the main branch supporting it had broken and the nest had fallen along with half of the tree.

\section{Midway Road}

During our surveys in 2014 and 2015, we observed a pair most often in survey plot 323, undulating and soaring together, and frequently perching on the transmission towers in the survey plot during nearly every survey occasion in which they were detected. We also detected a pair once in northern survey plot 307 during 2014 which we assumed was the Midway Road pair, but this is also an area in which we later observed pairs associated with the Patterson Pass and Telsa territories. In early 2016, we found one adult on a frequently-used perch in a transmission tower and located a golden eagle carcass on the ground nearby, which appeared to be a subadult or adult based on plumage. The cause of death was unknown because the carcass was desiccated and scavenged, and no operational wind turbines were located in the area. During subsequent surveys, we observed a pair soaring, hunting, and perching together nearby, but outside our focal area in southwest survey plot 338 and northeast survey plot 330. It was unclear if the dead eagle was a member of the territorial pair. In mid-May, while watching the Midway Road pair on another frequently used perch in southwest survey plot 338, we simultaneously observed a second adult pair hunting and soaring together close by in survey plot 330 . It was unknown if this pair was associated with any of the known territories nearby, given our limited observations and search effort outside the focal survey plots nearby. We also found no evidence of nesting by golden eagles in the area, although we also documented some large stick nests in transmission towers nearby that would potentially provide suitable nesting substrates for this pair. In 2014, both pair members were confirmed to be adults, but in 2015 and 2016, one of them, possibly the female, appeared to have white in the outer tail feathers consistent with that of a third-year subadult or first-year adult with delayed plumage (Bloom and Clark 2002). Raptor surveys along the transmission line have also documented at least one subadult pair in this area in 2012 and 2013 (Garcia and Associates, 2013). In spring 2016, another researcher observed an eagle pair flying together near wind turbines overlapping with the activity center we identified, and found a female near a wind turbine shortly afterwards with a freshly severed wing (S. Smallwood, independent consultant, written commun., 2016.). 


\section{Silva}

This area was outside our survey plots, but in 2015 and 2016, we frequently observed an adult pair perching and undulating together on the western side of Vasco while simultaneously watching the nearby Windy Valley pair during our survey of plot 345 . This area roughly aligns with a pair often observed to the southwest of the Los Vaqueros Watershed that is potentially part of the historical Silva territory (The Wildlife Project, 2016; H. T. Harvey and Associates, 2017).

\section{Windy Valley, Howden, and Vasco}

These historical territories are located on land owned by the Contra Costa Water District and have been monitored annually since 1994 as part of a separate study on the Los Vaqueros Watershed (The Wildlife Project, 2016; H. T. Harvey and Associates, 2017). This survey information has been shared with our study, but nest locations have been censored in figure 2 because of the sensitive nature of these data near hiking trails. In all 3 years, these pairs were determined to be adults. Generally, a pair associated with the Windy Valley territory was observed in northern survey plot 336, northwestern survey plot 345 , and southern half of survey plot 353 . In all 3 years, they used the same nest located between survey plots 336 and 352. In 2014 and 2015, they were primarily observed in the area overlapping with survey plot 352 and failed in their nesting attempts. However, in 2016, they were nearly always observed outside of our focal survey plot in 336 and fledged one young. The Howden territory, roughly overlapping outside of our focal area in survey plot 361 , has been occupied every year from 1998 to 2016. Long-term monitoring has determined that the last time a pair nested in this territory was in 2009 from the only known nest. The Vasco territory has historically, and during our study, been occupied, but overlapping outside of our focal survey area in northern survey plot 361, western survey plot 370, and southern survey plot 377. A pair associated with this territory fledged one young each year in 2014 and 2016 from different nests in plot 377.

\section{Brushy Peak}

Each year, we observed a pair perching and undulating together throughout survey plot 345, and in the northern survey plot 329 and western survey plot 337 on multiple occasions ( 8 of 10 surveys over 3 years). However, we found that monitoring pair activity was very difficult in this area because it was not possible for a single observer to maintain visual observations of the pair as they often flew behind Brushy Peak and out of view. Additionally, we frequently detected five or more subadult and juvenile golden eagles and occasionally bald eagles (Haliaeetus leucocephalus) near Brushy Peak, a known roost location for these species, simultaneously. We did not observe the pair responding aggressively to the younger eagles and instead found them perching together elsewhere on top of the peak and appearing to undulate only in response to other territorial pairs nearby, such as the Brushy Creek pair to the east. In 2014, both pair members were confirmed to be adults, but in 2015 and 2016, at least one pair member was a second- or third-year subadult. The subadult was most likely the female based on size difference when the pair was observed perched together, but we were unable to observe a copulation that could have provided stronger evidence of the sex for each age-class. The only known nest location for this pair was last used in 1989 (Howell and DiDonato, 1991), and we found no evidence of nesting activity by territorial golden eagles in this area during our surveys. 


\section{Brushy Creek}

In 2014, the male associated with this territory was observed to be a second- or third-year subadult every time it was detected, based on the large amount of white at the base of most tail feathers, and the female an adult. In 2015, a male associated with this territory had some retained outer subadult rectricies, but by 2016, both individuals were determined to be adults as no white was observed in the tail feathers at any point during extensive observations. From 2014 to 2016, we detected the pair undulating together in southern survey plot 353 and the eastern half of survey plot 337, often perching together on utility poles and old-generation lattice tower turbines on the eastern side of the Brushy Creek drainage. We also observed them constructing/refurbishing a nest in a eucalyptus tree approximately $200 \mathrm{~m}$ from the nearest newer generation turbine in 353 during all 3 years. The pair was observed adding a grass lining to this nest in 2016, but we found no evidence they ever laid eggs. Aside from refurbishing this nest, most of the activity by this pair in 2016 was observed in the adjacent survey plot 337 (that is, copulating, pair perching, hunting together, and undulating). This pair was also frequently seen near the many younger conspecifics in the area, but during our observations, only displayed aggression towards other territorial pairs. In 2015, we discovered the primary Brushy Creek pair perch area in southern survey plot 353 was near a second eagle roost location where 6-10 subadults and juvenile golden eagles were seen flying together and at least 6 more were perched in a tree below, during one survey alone and all simultaneously. In 2016, we observed the pair undulating together in the same area between survey plots 337 and 353, seemingly in response to the nearby Brushy Peak pair. They appeared to ignore the 3-4 younger eagles perched on nearby turbines, including a subadult that chased after them repeatedly while vocalizing with "begging" calls.

\section{Bethany}

Determining territory occupancy in this area has been difficult because large numbers of eagles from all age classes were often observed near the pair simultaneously during surveys. However, on numerous survey occasions each year from 2014 to 2016, we observed an adult pair or mixed-age pair, primarily perching on old-generation lattice tower turbines, transmission towers, and utility poles, and undulating on the western side of Bethany Reservoir in survey plot 346. We found no sign of nesting activity, although the sparse clusters of large eucalyptus trees and transmission towers would potentially provide suitable nesting substrates in the area. In 2014, the male was an adult, but the female appeared to be either a third-year subadult or first-year adult (as in, just prior to the onset of pre-definitive molt; Bloom and Clark 2002) based on one observation of white at the base of the outer-most tail feathers. In 2015 , both pair members were confirmed to be adults, but in 2016, the female again appeared to be a third-year subadult or first-year adult with delayed plumage. A pair of golden eagles was also observed in this area during transmission line surveys in 2012 and 2013, but was suspected to be part of the adjacent Byron territory (Garcia and Associates, 2013). 


\section{Christiansen Road}

We detected a territorial adult pair of golden eagles nesting on transmission towers in southern survey plot 354 each year from 2014 to 2016. In 2014, this pair fledged one young, but failed in their nesting attempts in the subsequent 2 years. In 2015, we observed the pair in incubation posture, then later brooding at least one young nestling in a second nest just inside the northern part of survey plot 338; the nest failed for unknown reasons and was taken over by a pair of ravens shortly thereafter. We observed one of the pair (an adult) in incubation posture on a third nest in 2016, but during our subsequent check we found the nest to be partially blown out of the transmission tower, having failed for unknown reasons. A red-tailed hawk pair was seen incubating in this third nest in 2014 and was observed refurbishing it again in 2016 after failure by the golden eagle pair.

\section{Byron}

Beginning in 1996, a territorial pair of golden eagles was suspected to occupy the area southwest of Byron Airport, an area overlapping with the intersection of our survey plots 353, 362, and 370. However, the pair was observed only intermittently, partly because of problems accessing the privately owned land (T. Hunt, The Peregrine Fund, oral commun., 2016), until 2012 (Garcia and Associates, 2013). We detected a pair in the same area during each year of our study. In 2014, they were primarily observed in survey plot 362. In 2015, they were first observed refurbishing a nest in survey plot 353, but it was instead used by great horned owls (Bubo virginianus). The eagles later hatched one young in a nearby nest approximately $710 \mathrm{~m}$ from the nearest newer generation wind turbine, but the nestling was not observed again after sometime between 3 and 7 weeks of age (D. Bell, East Bay Regional Park District, written commun., 2015). The nest used by the eagle pair in 2015 and 2016 and the alternate nest used by great-horned owls were both in eucalyptus trees. In 2016, the pair fledged one young from the 2015 nest. In all 3 years, both pair members were adults.

\section{Vaquero Farms}

In 2014, we observed a territorial adult in survey plot 370 and an adult pair to the west nearby on the Los Vaqueros Watershed lands. We were unsure if the lone adult was occupying a new and previously unknown territory or if it was paired because this area has long been thought to be part of the adjacent Vasco and Walnut territories which have historically overlapped with the Los Vaqueros Watershed land (The Wildlife Project, 2016; H.T. Harvey and Associates, 2017). In 2015 and 2016, we frequently detected a territorial pair consisting of an adult and a second- or third-year subadult male perching, hunting, and undulating with his mate throughout survey plot 370. During our 2015 surveys, this pair was also observed engaged in territorial disputes with the Brushy Creek and Byron pairs to the south. We did not obtain simultaneous observations of the pair in this territory with those attributed to the Walnut and Vasco territories to the north and west, aside from our observations of a lone adult and separate adult pair seen at the same time in 2014. However, the Vasco territory has been occupied by an adult pair during all 3 years of our study, and the Walnut territory consisted of a subadult female and adult male in 2014 and 2015. In 2016, a pair attributed to the Walnut territory nested farther to the north outside of the $3.2 \mathrm{~km}$ buffer and consisted of an adult male and female. Additionally, we did observe pairs associated with Vaquero Farms, Brushy Creek, and Byron at the same time in 2015. Our observations of a territorial subadult male in Vaquero Farms from 2015 to 2016 suggest this pair is occupying a different territory, but simultaneous observations of all adjacent territorial pairs, especially Walnut, may be necessary to provide further confirmation. We have not located any nests associated with this pair in survey plot 370 . 
Publishing support provided by the U.S. Geological Survey Science Publishing Network, Tacoma Publishing Service Center

For more information concerning the research in this report, contact the Director, Forest and Rangeland Ecosystem Science Center U.S. Geological Survey

777 NW 9th St., Suite 400

Corvallis, Oregon 97330

http://fresc.usgs.gov/ 
